G. Klaus • A. Watson - A. Edefonti - M. Fischbach •

K. Rönnholm • F. Schaefer • E. Simkova •

C. J. Stefanidis • V. Strazdins • J. Vande Walle •

C. Schröder · A. Zurowska • M. Ekim

\title{
Prevention and treatment of renal osteodystrophy in children on chronic renal failure: European guidelines
}

Received: 23 November 2004 / Revised: 28 June 2005 / Accepted: 29 June 2005 / Published online: 25 October 2005

(C) IPNA 2005

The authors are members of the European Pediatric Dialysis Working Group (EPDWG)

\author{
A. Edefonti \\ Fondazione IRCCS Ospedale Maggiore Policlinico, \\ Mangiagalli e Regina Elena, Milan, Italy \\ M. Fischbach \\ Hospital de Hautepierre, Strasbourg, France \\ K. Rönnholm \\ University of Helsinki, Helsinki, Finland \\ F. Schaefer \\ University of Heidelberg, Heidelberg, Germany \\ E. Simkova \\ University Hospital Motol, Prague, Czech Republic \\ C. J. Stefanidis \\ A\&P Kyriakou Children's Hospital, Athens, Greece \\ V. Strazdins \\ University Hospital for Children, Riga, Latvia \\ J. Vande Walle \\ University of Ghent, Ghent, Belgium
}

A. Watson

Nottingham City Hospital, Nottingham, UK

C. Schröder

Wilhelmina Kinderziekenhuis,

University of Utrecht, Utrecht, The Netherlands

A. Zurowska

University of Gdansk, Gdansk, Poland

M. Ekim

University of Ankara, Ankara, Turkey

G. Klaus $(\bowtie)$

Department of Pediatrics, University of Marburg,

Deutschhausstrasse 12, 35033 Marburg, Germany

e-mail: klaus@med.uni-marburg.de

Tel.: +49-6421-2862670

Fax: +49-6421-2865427
Abstract Childhood renal osteodystrophy (ROD) is the consequence of disturbances of the calcium-regulating hormones vitamin D and parathyroid hormone (PTH) as well as of the somatotroph hormone axis associated with local modulation of bone and growth cartilage function. The resulting growth retardation and the potentially rapid onset of ROD in children are different from ROD in adults. The biochemical changes of ROD as well as its prevention and treatment affect calcium and phosphorus homeostasis and are directly associated with the development of cardiovascular disease in pediatric renal patients. The aims of the clinical and biochemical surveillance of pediatric patients with CRF or on dialysis are prevention of hyperphosphatemia, avoidance of hypercalcemia and keeping the calcium phosphorus product below $5 \mathrm{mmol}^{2} / \mathrm{l}^{2}$. The PTH levels should be within the normal range in chronic renal failure (CRF) and up to 2-3 times the upper limit of normal levels in dialysed children. Prevention of ROD is expected to result in improved growth and less vascular calcification.

Keywords Chronic renal failure $\cdot$ Secondary hyperparathyroidism - Calcium-phosphate product - Vitamin D . Parathyroidectomy

\section{Introduction}

Chronic renal failure is associated with specific abnormalities of skeletal homeostasis, commonly called renal osteodystrophy (ROD), which if not treated appropriately during the critical phases of skeletal growth can result in bone deformities and a disturbed growth pattern. The main factors for the development of ROD are disturbances in the calcium phosphate homeostasis, in vitamin $\mathrm{D}$ and parathyroid hormone metabolism as well as alterations in the somatotroph axis, i.e., on the endocrine and paracrine levels. In recent years it has been recognized that the spectrum of renal bone disease covers 'high-' as 
Table 1 Frequency of measurements for biochemical and radiological markers of renal osteodystrophy

\begin{tabular}{|c|c|c|c|c|}
\hline \multirow[t]{2}{*}{ Marker $^{1}$} & \multicolumn{3}{|c|}{ Frequency of measurement (every x month) } & \multirow[t]{2}{*}{ Target } \\
\hline & $\begin{array}{l}\text { GFR } \\
59-30\end{array}$ & $\begin{array}{l}\text { GFR } \\
29-15\end{array}$ & $\begin{array}{l}\text { GFR }<15 \text {, dialysis } \\
\text { (Evidence) }\end{array}$ & \\
\hline Calcium or & 6 & 3 & 1 & Normal range (corrected calcium $)^{2}$ \\
\hline Phosphate & 6 & 3 & 1 & Normal range for age band \\
\hline $\begin{array}{l}\text { Calcium phosphorus } \\
\text { product }\end{array}$ & 6 & 3 & 1 & $\begin{array}{l}\leq 5.0 \mathrm{mmol}^{2} / \mathrm{l}^{2} \\
\text { Target range } 3.3-4.4 \mathrm{mmol}^{2} / \mathrm{l}^{2,3}\end{array}$ \\
\hline Intact PTH/whole PTH & 6 & 3 & 1 & $\begin{array}{l}\text { Normal range in moderate CRF } \\
\left(\mathrm{GFR}>29 \mathrm{ml} / \mathrm{min} / 1.73 \mathrm{~m}^{2}\right)\end{array}$ \\
\hline $\begin{array}{l}25-(\mathrm{OH}) \text { vitamin } \mathrm{D}_{3} \\
\text { Left hand and wrist } \mathrm{X} \text {-ray }\end{array}$ & As indicated ${ }^{4}$ & As indicated ${ }^{4}$ & $\begin{array}{l}\text { As indicated } \\
6-12\end{array}$ & $\begin{array}{l}\text { Up to } 2-3 \text { times upper limit of normal } \\
\text { in advanced CRF or on dialysis } \\
>20 \mathrm{ng} / \mathrm{l} \\
\text { No radiological signs of hyperparathyroidism } \\
\text { No Looser zones or osteopenia }\end{array}$ \\
\hline
\end{tabular}

Calcium: $\mathrm{mmol} / \mathrm{l}$ in $\mathrm{mg} / \mathrm{dl}: \times 4$, phosphate $\mathrm{mmol} / \mathrm{l}$ in $\mathrm{mg} / \mathrm{dl}: \times 3.0969$; calcium phosphorus product: $\mathrm{mmol}^{2} / \mathrm{l}^{2}$ in $_{\mathrm{mg}}{ }^{2} / \mathrm{l}^{2}: \times 12.387 .{ }^{2} \mathrm{Corrected}$ calcium $(\mathrm{mg} / \mathrm{dl})=$ measured calcium concentration $(\mathrm{mg} / \mathrm{dl})+0.8 \times[4$-measured albumin concentration $(\mathrm{g} / \mathrm{dl})]$; corrected calcium $(\mathrm{mmol} / \mathrm{l})$ $=$ measured calcium concentration $(\mathrm{mmol} / \mathrm{l})+0.2 \times[4$-measured albumin concentration $(\mathrm{g} / \mathrm{dl})] .{ }^{3}$ Depending on age. ${ }^{4}$ Only in patients with suspected vitamin D deficiency

well as 'low-turnover' conditions. As a consequence of chronic renal failure itself and of the treatment of renal bone disease, high plasma phosphate levels and an elevated calcium phosphorus product are common. These are important risk factors for the development of vascular calcification and cardiovascular morbidity and mortality in young adults who have been on renal replacement therapy since childhood $[1,2]$. Because aluminium-containing phosphate binders are no longer indicated in children, aluminium-related osteopathy is not considered in these recommendations.

The European Pediatric Peritoneal Working Group (EPPWG) was established in 1999 by pediatric nephrologists with a major interest in peritoneal dialysis and has, among others, published guidelines on chronic and acute peritoneal dialysis $[3,4,5,6]$. The group incorporates pediatric nephrologists from 12 European countries. One of the functions of the group is to establish expert guidance in important clinical areas associated with chronic renal failure and dialysis [now the European Pediatric Dialysis Working Group (EPDWG)] in conjunction with other members of the multidisciplinary team. These guidelines were initiated and discussed at meetings of the group and developed by e-mail discussion to develop consensus of opinion based upon cumulative clinical experience and reported studies.

\section{Recommendations}

\section{Recommendation 1}

Clinical, biochemical and radiological markers of renal bone disease should be monitored regularly. The clinical markers of renal bone disease to be prevented are signs of overt rickets, slipped femoral epiphysis and disturbances of growth. The biochemical markers are plasma phosphate, calcium, alkaline phosphatase, bicarbonate and intact parathyroid hormone (PTH). The minimal frequency of measurements (and target ranges) for biochemical markers in a stable phase vary according to renal function (Table 1). If the patient has active ROD, additional blood samples may be required.

Plasma calcium must be adjusted for albumin levels (= corrected calcium) or by measuring ionized (free) calcium, in patients with hypoalbuminemia or acid-base disorders. Ionized calcium values are often available on blood gas analysis systems with calcium-sensitive electrodes, but correct values are only obtained in validated conditions. Alkaline phosphatase as a marker for osteoblast activity has particular importance in both low and high-turnover bone disease with elevated or low alkaline phosphatase serum levels, respectively.

PTH should be monitored monthly in advanced CRF (GFR $<15 \mathrm{ml} / \mathrm{min} / 1.73 \mathrm{~m}^{2}$ ) because of its rapid changes. Different assays are available for the measurement of PTH. In principle, intact PTH(1-84) (iPTH) should be measured because it is believed to represent the active hormone. For this purpose, two-site assays were developed at the end of the 1980s [7]. However, PTH fragments accumulating in end-stage renal disease may also show biological activity. Furthermore, recent research using plasma samples from healthy and renal patients analyzed by HPLC and the iPTH assay demonstrated cross-reactivity of the intact PTH-assay with a PTH-fragment (PTH7-84). Therefore, new assays were developed that detect only PTH molecules with a complete N-terminal end, called "whole-PTH" assays [8]. In adult and pediatric dialysis patients, these "whole PTH" assays yielded 30 $60 \%$ lower PTH levels than the intact PTH assay. Despite theoretical considerations, no significant improvement in the distinction between the different forms of renal bone disease using the "whole PTH" assays has yet been demonstrated in clinical practice $[9,10,11,12]$. 
Radiological signs of renal bone disease, which alone are not sensitive enough to indicate therapy-adaptations, include signs of hyperparathyroidism and growth zone lesions. Periosteal resorption zones and metaphyseal changes are the most obvious signs. In late adolescent and young adult patients, Looser zones as specific signs of osteomalacia may be found. The sites and expression of bone lesions are age-dependent according to the age-dependent growth and remodeling at different sites of the skeleton. In pre-school children, the metaphysis of the distal radius and ulna may present only minor abnormalities, whereas more severe lesions may be seen at the upper and lower femoral epiphysis. Adynamic bone disease shows no specific radiological changes. However, extraosseous calcifications, fractures or osteopenia may indicate adynamic bone disease.

Histological evaluation of bone biopsy specimens remain the "gold standard" in assessment of renal osteodystrophy. However, due to its invasive nature, bone biopsies are not performed in clinical practice, but they remain an important tool for research [12].

\section{Recommendation 2}

Metabolic acidosis should be corrected (evidence). Chronic metabolic acidosis leads to increased bone resorption and inhibits endochondral bone formation in animal experiments $[13,14]$. Infants with isolated chronic metabolic acidosis show growth retardation [14]. In adult hemodialysis patients, negative aspects of chronic metabolic acidosis on metabolism have been reported [15]. Therefore, metabolic acidosis should be corrected by a stepwise approach: The first step is optimization of the dialysis regimen both for HD- and PD-patients [4, 15]. Since the introduction of $\mathrm{HCO}_{3}$-based PD solutions [16], metabolic acidosis is a less frequent problem. In combination with a daytime-dwell, patients may even be at risk for alkalosis [17]. However, if these adaptations do not result in correction of the metabolic acidosis, sodium bicarbonate should be administered orally. Whenever possible, formulations that dissolve in the small intestine should be used. The use of sodium citrate increases the risk of aluminium absorption $[18,19]$. Acidosis should be corrected to the normal range of the local laboratory.

\section{Recommendation 3}

The plasma-phosphate level should be kept within the normal age-specific range (evidence). In children with chronic renal failure, hyperphosphatemia is observed at GFR levels below $40 \mathrm{ml} / \mathrm{min} / 1.73 \mathrm{~m}^{2}$ [20] and almost always in children on dialysis. Hyperhosphatemia has several deleterious effects on PTH secretion [21, 22], parathyroid cell proliferation [23] and soft tissue (vascular) calcification $[1,2]$.

Increased phosphate levels stimulate PTH secretion in vitro [24] and in vivo [21, 25] independent of calcium and
$1,25(\mathrm{OH})_{2}$ vitamin $\mathrm{D}_{3}$ levels. This effect of phosphate on PTH secretion occurs via post-transcriptional processes by regulating pre-pro-PTH mRNA stability [26]. Furthermore, a reduction of serum-phosphate results in a parallel reduction of PTH levels without change in serum calcium [27]. Hyperphosphatemia accelerates parathyroid cell proliferation [23], which can result in nodular hyperplasia and severe hyperparathyroid bone disease necessitating parathyroidectomy (see below).

Increased plasma phosphate levels have a profound effect on soft tissue and vascular calcification, which are often observed in young patients on or even after dialysis $[1,2,28]$, increasing the risk of cardiovascular morbidity and mortality. Block et al. [29] found an increased risk of death for serum phosphate exceeding $2.09 \mathrm{mmol} / \mathrm{l}$ in adult patients; other studies described a much lower phosphate level $(\sim 1.4-1.6 \mathrm{mmol} / \mathrm{l})$ at which a higher incidence of calcifications was found $[1,30,31]$. The histology of the calcification pattern is quite distinct from the process of atherosclerosis. In renal patients, extensive calcification of the tunica media occurs even after short periods of dialysis, as shown by investigations of the epigastric artery in adult patients [32]. Experimental work gave evidence for an active role of phosphate in this process as phosphate induces osteoblastic marker followed by calcification in cultured smooth muscle cells [33]. Dialysis patients are at risk of heart failure. Although this is a multifactorial process, it was demonstrated in animal experiments that high plasma phosphate levels per se accelerated cardiac fibrosis [34].

\section{Recommendation 4}

If plasma phosphate is elevated, phosphate intake should be limited to the recommended levels. Dietary intake of protein and as a consequence of phosphate in western countries usually exceeds the recommended intake at least in adolescent dialysis patients. Therefore, dietary counseling should be performed by a trained dietician [35]. If the dietary records show a protein intake above the recommended level for pediatric dialysis patients, the patients and their parents should be trained to reduce their phosphate intake. This may start with the reduction of dairy products and/or substitution with special low-phosphorus products and a reduction of meat intake.

\section{Recommendation 5}

In case of hyperphosphatemia, the dialysis efficacy should be optimized (evidence). Phosphate is slowly transported via the peritoneal membrane into the dialysate [36]. The dialysate to plasma ratio (D/P) for phosphate is volume and time related; after $4 \mathrm{~h}$ in standard peritoneal equilibration tests, this ratio reaches the value of $0.5-0.6$, which is a much lower ratio than for urea, which is usually nearly 1 . Therefore, an increase in phosphate removal 
should consider not only an increase in dwell volume to $1,000-1,400 \mathrm{ml} / \mathrm{m}^{2}$ BSA, but also dwell time optimization, avoiding a too short dwell time. A daytime dwell should be added. The details of a dialysis regimen optimization has been described elsewhere [5]. However, due to the low clearance of phosphate achievable even with an optimized PD regimen, dietary phosphate restriction and the use of oral phosphate binders are almost always necessary.

The dialytic phosphate removal kinetic during a hemodialysis session differs from urea kinetic: after an early initial drop the phosphatemia decrease only slowly [37, 38]. Therefore, it is admitted that the hemodialysis phosphate purification capacity is directly impacted by the duration of the dialysis session, because the phosphate shift from the intracellular to the vascular compartment is time-dependent. Therefore, longer dialysis sessions [39] or daily dialysis sessions [40,41, 42] offer a unique, powerful dialysis method for optimal phosphate purification. The hemodialysis modality, HD, HF or HDF, and the type of the synthetic membrane used have only a limited impact on dialytic phosphate removal [38], whereas the dialysate composition in terms of glucose and bicarbonate concentration are presumed to be of importance [42, 43, 44], modulating a shift of intracellular phosphate trapped in the cells, where it is not available for dialysis exchanges.

\section{Recommendation 6}

For control of hyperphosphatemia, aluminium-free phosphate binders should be administered (evidence). Phosphate binders are necessary to reduce phosphate absorption from the gut. Ca-containing phosphate binders, i.e., calcium carbonate $\left(\mathrm{CaCO}_{3}\right.$, elemental calcium content $40 \%$ ) or calcium acetate (CaAc, elemental calcium content $25 \%$ ) should be used as the first line. No data are published on the efficacy and safety of calcium acetate/ magnesium carbonate compound phosphate binders in pediatric patients. The upper intake level of elemental calcium is suggested to be $2,500 \mathrm{mg} /$ day for healthy children above 4 years of age [19]. Whereas for adult dialysis patients the DOQI guidelines suggest to limit the elemental calcium intake to $2,000 \mathrm{mg} /$ day, no safe upper level can be given for the pediatric age band. However, a positive calcium balance in the range of $+200-+300 \mathrm{mg}$ in the growing skeleton should be maintained. In contrast, a too high calcium load should be avoided, because one of the identified risk factors for soft tissue calcification in pediatric CRI patients was cumulative calcium intake [2, 24].

Calcium-containing phosphate binders are started at approximately $500 \mathrm{mg}$ per $200 \mathrm{mg}$ phosphate content of the diet $(0-1$ years, $1-2 \times 500 \mathrm{mg} ; 1-4$ years, $2-3 \times 500 \mathrm{mg} /$ day; 5-8 years, 3-4×500 mg/day; $9-18$ years, $5 \times 500 \mathrm{mg}$ ). An alternative approach is a start dose of approximately $50 \mathrm{mg} / \mathrm{kg} / \mathrm{day}$, which is well below the doses given in clinical studies. Phosphate binders are then adjusted to normalize serum-phosphate and calcium. $\mathrm{CaCO}_{3}$ can be crushed to fine powder, or a $10 \%$ solution can be used for administration in infants, often via a feeding tube. The phosphate binders should be taken with meals, because fecal excretion of phosphate was higher when calcium acetate was given with meals instead of in between meals [45]. Biochemically, CaAc has a higher phosphate binding capacity, which is independent of the $\mathrm{pH}$. The higher efficacy of $\mathrm{CaAc}$, calculated on a weight basis compared to $\mathrm{CaCO}_{3}$, for phosphate control was also shown in clinical practice in adult and pediatric patients [46, 47]. Unfortunately, compliance of the patients with the intake of phosphate binders is often poor and should be checked regularly. It may be helpful if the patient is involved in selecting the flavor and size of the phosphate binder and has regular contact with the dietician at clinic appointments. Snacks during the day are often a source of additional phosphate and require additional phosphate binders.

Patients treated with Ca-containing phosphate binders and active vitamin D metabolites are particularly at risk for the development of hypercalcemia. Therefore, in case of hypercalcemia, active vitamin D metabolites should be stopped (see recommendation 12). If hypercalcemia, the most common side-effect of Ca-containing phosphate binder therapy, persists or the calcium phosphorus product exceeds $5.0 \mathrm{mmol}^{2} / \mathrm{l}^{2}$ with the use of Ca-containing phosphate binders, the calcium content in the dialysis fluid should be reduced [5]. Furthermore, the dose of the calcium-containing phosphate binders should be reduced whenever possible or they should be replaced by $\mathrm{Ca}-$ and aluminium-free phosphate binders, because epidemiological studies have shown a direct relationship between serum phosphate and calcium phosphorus product on mortality [29, 48]. The only commercially available aluminium- and calcium-free phosphate binder is Sevelamer. This compound is usually taken orally as capsules, but anecdotally can be delivered via enteral tubes by dissolving the capsule in $5 \mathrm{ml}$ water (instruction Fa genzyme). Aluminium-containing phosphate binders or calcium citrate increase intestinal aluminium absorption and should not be used in pediatric dialysis patients. An alternative phosphate binder that is available is lanthanum carbonate, which has a high affinity for phosphate, and is minimally absorbed in the intestine. In a randomized study in adult patients, lanthanum carbonate controlled plasma phosphate levels well and induced less adynamic bone disease than $\mathrm{CaCO}_{3}$ [49]. However, no long-term data on the effect of lanthanum on bone, on which surface lanthanum can accumulate [50], and its safety profile for use in children are available yet.

\section{Recommendation 7}

Vitamin D deficiency should be avoided (evidence). In early renal failure, an increase of PTH correlates positively with $25(\mathrm{OH})$-vitamin $\mathrm{D}_{3}$ levels [51]. Renal synthesis of $1,25(\mathrm{OH})_{2} \mathrm{D}_{3}$ is impaired in chronic renal dis- 
ease. However, extrarenal cells, i.e., macrophages and osteoblasts, are also capable of $1,25(\mathrm{OH})_{2} \mathrm{D}_{3}$ production [52]. In contrast to the kidney, the extra-renal synthesis is strictly substrate dependent. It has been shown that supplementation with vitamin $D_{3}$ in elderly CRF patients with $25(\mathrm{OH})$-vitamin $\mathrm{D}_{3}$ levels between 20 and $50 \mathrm{pg} / \mathrm{ml}$ decreased PTH serum concentrations [53]. Furthermore, 25-OH-vitamin $\mathrm{D}_{3}$, but not $1,25(\mathrm{OH})_{2} \mathrm{D}_{3}$, improved muscular function and phosphate content [54]. Therefore, vitamin D deficiency should be prevented.

\section{Recommendation 8}

Marked hyperparathyroidism should be prevented in children with CRF prior to dialysis (evidence). Due to the risk of persisting bone disease and the development of parathyroid adenoma, an increase in PTH above normal to slightly elevated levels should be prevented in children with CRF. Therefore, low doses of active vitamin D metabolites should be given in time. In adult patients this treatment regimen has resulted in controlled iPTH without negative aspects [55]. In children with moderate renal failure (GFR $>30 \mathrm{ml} / \mathrm{min} / 1.73 \mathrm{~m}^{2}$ ), normal levels of PTH in association with strictly controlled phosphate levels are associated with a normal ratio of intact PTH to "whole" PTH and normal levels of alkaline phosphatase, indicating a physiological PTH secretion and unremarkable bone turnover [10]. In such patients, slight catch-up growth with PTH levels at the upper limit of normal was reported [56]. In a sub-group analysis, improved growth was restricted to patients with enteral feeding tubes.

\section{Recommendation 9}

PTH levels should be kept at two to three times the upper limit of the normal range in end-stage renal disease (evidence). Grossly elevated PTH concentrations (>four times the upper normal range) in the presence of normal or high serum calcium and high alkaline phosphatase are almost always associated with high-turnover bone disease [56, 57]. The exception is intermittent therapy with high-dose active vitamin $\mathrm{D}$ metabolites, because $1,25(\mathrm{OH})_{2}$ vitamin $\mathrm{D}_{3}$ directly inhibits osteoblastic function and proliferation. Hyperphosphatemia can occur in hyperparathyroid bone disease because of excessive bone resorption.

However, in pediatric dialysis patients low and even normal levels of PTH are reported to be associated with low turnover bone disease [57]. A PTH concentration higher than in healthy subjects is needed to stimulate bone turnover due to resistance of the skeleton to PTH in advanced renal failure. If PTH falls into the (low) normal range, the risk of hypercalcemia increases [58]. Hyperphosphatemia and hypercalcemia can develop in low turnover bone disease because the skeleton is unable to take up enough phosphate and calcium. Low bone turnover or adynamic bone disease is increasingly observed in adult [59] as well as in pediatric PD patients [56]. Risk factors for adynamic bone disease are high calcium intake (Ca-containing phosphate binders), therapy with high doses of active vitamin D metabolites, peritoneal dialysis using dialysis fluid with high calcium content and age (adolescents after the growth spurt). Biochemically, hypercalcemia and/or PTH levels within or below the normal range are indicative of low turnover bone disease [56, 58], which may adversely affect growth in dialysed children [60]. Therefore, active vitamin D therapy should be reduced or stopped if PTH falls below the low normal range $[57,59,61]$. If PTH remains below normal despite normal calcium and phosphate levels, the dialysate should be changed to low calcium solutions ( 1.0 or $1.25 \mathrm{mmol} / \mathrm{l})$ to stimulate PTH secretion [61], if this is not already used as the standard solution [5].

\section{Recommendation 10}

If PTH is elevated in children with CRF or if PTH is elevated more than two to three times normal in the presence of $\mathrm{Pi}<2 \mathrm{mmol} / \mathrm{l}$ in dialyzed children, active vitamin D metabolites should be administered orally (evidence). Treatment with active vitamin D metabolites results in biochemical and/or histological improvement in patients with high-turnover bone disease. Doses of $1,25(\mathrm{OH})_{2}$ vitamin $\mathrm{D}_{3}$ or $1 \alpha-(\mathrm{OH})$ vitamin $\mathrm{D}_{3}$ usually range from $0.1 \mu \mathrm{g} / \mathrm{day}$ to $0.75 \mu \mathrm{g} / \mathrm{day}$, with a starting dose of 20-40 ng/kg. High doses often induce hypercalcemia, necessitating the reduction or discontinuation of vitamin D therapy (see hypercalcemia).

As to the mode of administration of the active vitamin D metabolites, intravenous or oral therapy, have the same efficacy [63]. Therefore, the oral route should be preferred in children on dialysis. Doses should be given in the evening, because fewer episodes of hypercalcemia have been reported compared to taking the vitamin D metabolites in the morning [64]. Intermittent therapy was shown to be effective to suppress elevated PTH serum levels [59]. However, recent data indicate that large intermittent $1,25(\mathrm{OH})_{2}$ vitamin $\mathrm{D}_{3}$ doses adversely affect bone turnover [57, 61, 65] and chondrocyte activity [66] resulting in low turnover bone disease and in reduced growth [65, 66, 67, 68]. In addition, episodes of hypercalcemia occur with similar frequency with the intermittent or oral administration of vitamin D metabolites [63, 69]; furthermore, the intermittent mode of administration was not shown to be more effective in suppressing PTH levels in adult [70] and pediatric [63] patients in prospective, randomized trials. For the above mentioned reasons, intermittent high-dose vitamin D therapy should be avoided in pediatric patients.

Three newer vitamin D analogs, so called "non-hypercalcemic" vitamin D analogs (doxercalciferol, paricalcitol and 22-oxa-calciferol), have been introduced in clinical use in adult patients with secondary hyperparathyroidism due to CRF. Despite their ability to induce less hypercalcemia in animal experiments, only one clinical 


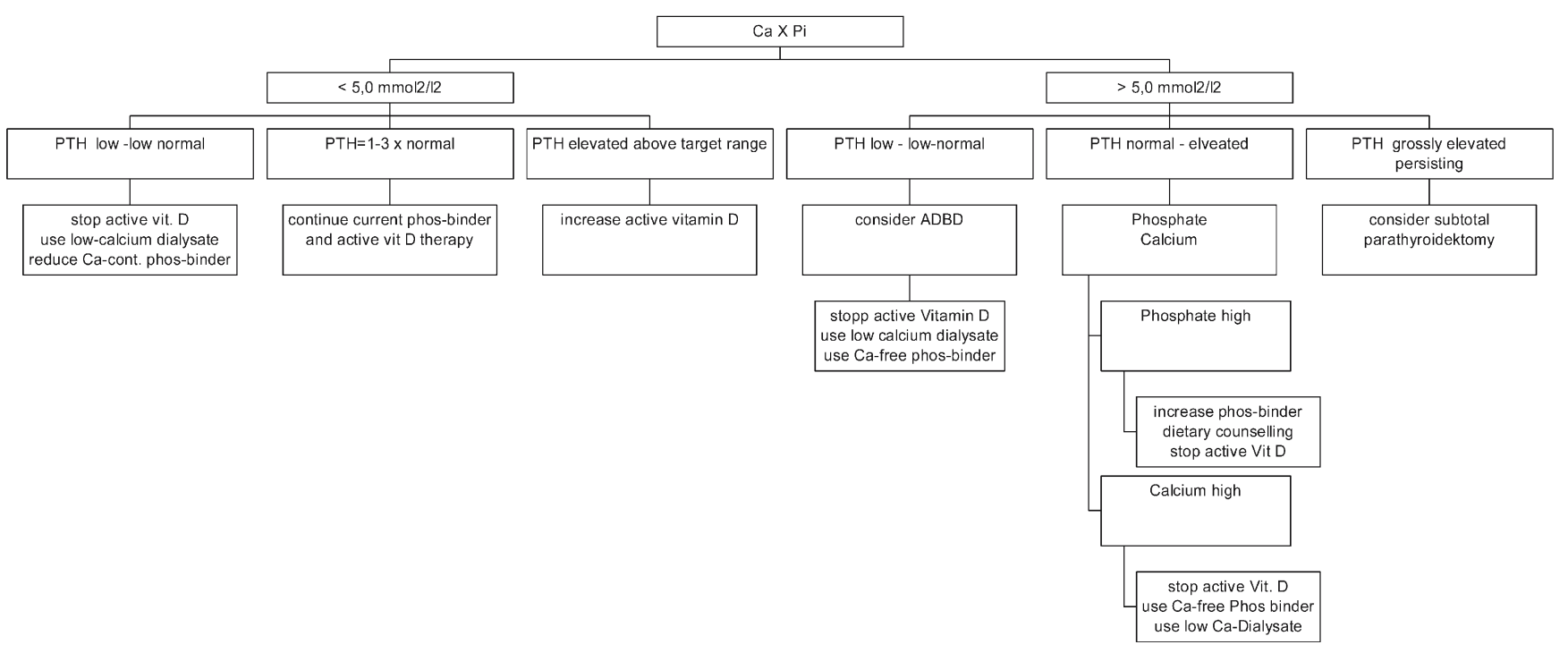

Fig. 1 Clinical algorithm for treatment of elevated calcium phosphorus product in children with CRF. Ca-cont calcium containing; Ca-free calcium-free; phos-binder phosphate binder; vit $D$ vitamin $\mathrm{D} ; A D B D$ adynamic bone disease

study with a head-to-head comparison of the new vitamin $\mathrm{D}$ analogue (paricalcitol) is available demonstrating a borderline reduction of hypercalcemia or a decrease in calcium phosphorus product [71]. No data are available for their use in children.

Agents that specifically enhance the sensitivity of the calcium-sensing receptor, called calcimimetics, used in combination with active vitamin D metabolites in adult dialysis patients resulted in a persistent decrease of PTH levels without elevated calcium phosphorus product [72]. If plasma $\mathrm{Ca}$ or $\mathrm{Pi}$ is high in the presence of elevated PTH, the calcimimetics may become first choice. However, no data for pediatric patients are available.

\section{Recommendation 11}

Treatment with growth hormone should not be started in the presence of severe hyperparathyroid bone disease. It is well established that the uremic growth retardation is at least in part due to disturbed pulsatile secretion of growth hormone as well as a peripheral growth hormone resistance [73]. After correction of metabolic acidosis and normalization of caloric intake, administration of recombinant human growth hormone increases growth velocity resulting in catch-up growth and in improved final height [74]. Growth hormone directly stimulates growth cartilage proliferation and metabolism and osteoblast activity $[75,76]$. This growth promoting effect of GH was suspected to increase the metaphyseal instability induced by severe hyperparathyroidism. In hyperparathyroid bone disease, i.e., osteitis fibrosa, a fibrous layer is formed at the metaphyseal junction of the growth plate with the bone tissue. This can lead to epiphyseal slipping resulting in gross deformities of the affected long bones [77]. Therefore, parathyroid hormone, as well as calcium and phosphate levels, should be treated towards the recommended normal ranges prior to administration of GH. However, in a recent prospective study, no increased frequency of epiphyseal slipping associated with the use of growth hormone was reported [78]. After the start of GH administration, an increase of PTH levels was observed $[79,80]$.

\section{Recommendation 12}

In case of hypercalcemia, active vitamin D metabolites and calcium-containing phosphate binders should be stopped and dialysate changed to low calcium solutions (evidence). Hypercalcemia and elevated calcium phosphorus product $\left(>5.0 \mathrm{mmol}^{2} / \mathrm{l}^{2}\right)$ should be corrected promptly (Fig. 1). Vitamin D metabolites should be discontinued and in case of persisting hypercalcemia the dialysate calcium decreased to low calcium dialysate. Laboratory values should be controlled weekly until improvement is seen. One exception is hypercalcemia due to severe hyperparathyroidism and high-turnover bone disease. In addition, in patients with residual renal function, loop diuretics, i.e., furosemide may increase calcium excretion. If hypercalcemia is not corrected despite the discontinuation of active vitamin D metabolites, calciumcontaining phosphate binders should be replaced by calcium-free phosphate binders to reduce the calcium load. Hypercalcemia is reported in up to $25 \%$ of patients taking calcium-containing phosphate binders $([1,29]$, see recommendation 6).

\section{Recommendation 13}

The calcium phosphorus product should be kept within the normal range, at least below $5.0 \mathrm{mmol}^{2} / \mathrm{l}^{2}\left(60 \mathrm{mg}^{2} /\right.$ $\mathrm{dl}^{2}$ ) (evidence). One of the risk factors for cardiovascular 
morbidity was shown to be an elevated calcium phosphorus product above $5.0 \mathrm{mmol}^{2} / \mathrm{l}^{2}$ (see also recommendation 2). If the calcium phosphorus product is elevated above this level, phosphate and/or calcium levels should be reduced. This may be achieved by an increase in phosphate binders, reduction/stopping of active vitamin D metabolites and use of low calcium $\left(\mathrm{Ca}^{++} 1.0-1.25 \mathrm{mmol} /\right.$ 1) dialysate.

\section{Recommendation 14}

Parathyroidectomy has to be considered in case of severe, therapy-refractory hyperparathyroidism with radiological signs in combination with hypercalcemia and/or elevated calcium phosphorus product (evidence). Severe hyperparathyroidism may no longer react to even high doses of $1,25(\mathrm{OH})_{2}$ vitamin $\mathrm{D}_{3}$ and reduction of phosphate levels. The clinical observations in adults show that patients with at least one parathyroid gland larger than $0.5 \mathrm{~cm}^{3}$ or $1.0 \mathrm{~cm}$ in diameter usually do not respond to active vitamin D metabolites [81, 82]. Therefore, persisting grossly elevated PTH levels in the presence of high-dose active vitamin D metabolites, radiological signs of hyperparathyroidism on wrist X-ray and/or high serum calcium and normal phosphate and/or elevated calcium phosphorus product indicate the need for surgical parathyroidectomy. Medical parathyroidectomy by alcohol injection was described in adult patients [83], but to our knowledge not in pediatric patients. Parathyroid hormone stimulates bone turnover and regulates calcium homeostasis, both of which are of utmost importance in the growing skeleton. Therefore, subtotal parathyroidectomy or autotransplantation of parathyroid tissue is recommended in children or adolescents, avoiding hypoparathyroidism ([84], review). However, these procedures carry the risk of recurrence of severe parathyroid tissue hyperplasia. The use of the new calcimimetic agents [85] may help to prevent the most severe hyperparathyroidism and therefore modify the approach to that condition.

\section{References}

1. Goodman WG, Goldin J, Kuizon BD, Yoon C, Gales B, Sider D, Wang Y, Chung J, Emerick A, Greaser L, Elashoff RM, Salusky IB (2000) Coronary-artery calcification in young adults with end-stage renal disease who are undergoing dialysis. $\mathrm{N}$ Engl J Med. 342:1478-1483

2. Oh J, Wunsch R, Turzer M, Bahner M, Raggi P, Querfeld U, Mehls O, Schaefer F (2002) Advanced coronary and carotid arteriopathy in young adults with childhood-onset chronic renal failure. Circulation 106:100-105

3. Watson AR, Gartland C (2001) European Paediatric Peritoneal Dialysis Working Group Guidelines by an Ad Hoc European Committee for Elective Chronic Peritoneal Dialysis in Pediatric Patients. Perit Dial Int 21:240-244

4. Schröder CH, European Paediatric Peritoneal Dialysis Working Group (2001) The choice of dialysis solutions in pediatric chronic peritoneal dialysis: guidelines by an ad hoc European committee. Perit Dial Int 21:568-574
5. Fischbach M, Stefanidis CJ, Watson AR, European Paediatric Peritoneal Dialysis Working Group (2002) Guidelines by an ad hoc European committee on adequacy of the paediatric peritoneal dialysis prescription. Nephrol Dial Transplant 17:380385

6. Schröder $\mathrm{CH}$, Watson AR on behalf of the European Paediatric Peritoneal Working Group (2001) The choice of dialysis solutions in chronic peritoneal dialysis: guidelines by an ad hoc European committee. Perit Dial Int 21:568-574

7. Blind E, Schmidt-Gayk H, Armbruster FP, Stadler A (1987) Measurement of intact human parathyrin by an extracting twosite immunoradiometric assay. Clin Chem 33:1376-1381

8. Gao P, Scheibel S, D'Amour P, John MR, Rao SD, SchmidtGayk H, Cantor TL (2001) Development of a novel immunoradiometric assay exclusively for biologically active whole parathyroid hormone 1-84: implications for improvement of accurate assessment of parathyroid function. J Bone Miner Res 16:605-614

9. Reichel H, Esser A, Roth HJ, Schmidt-Gayk H (2003) Influence of PTH assay methodology on differential diagnosis of renal bone disease. Nephrol Dial Transplant 18:759-768

10. Waller S, Reynolds A, Ridout D, Cantor T, Gao P, Rees L (2003) Parathyroid hormone and its fragments in children with chronic renal failure Pediatr Nephrol 18:1242-1248

11. Salusky IB, Goodman WG, Kuizon BD, Lavigne JR, Zahranik RJ, Gales B, Wang HJ, Elashoff RM, Juppner H (2003) Similar predictive value of bone turnover using first- and second-generation immunometric PTH assays in pediatric patients treated with peritoneal dialysis. Kidney Int 63:1801-1808

12. Martin KJ, Olgaard K, Coburn JW, Coen GM, Fukagawa M, Langman C, Malluche HH, McCarthy JT, Massry SG, Mehls O, Salusky IB, Silver JM, Smogorzewski MT, Slatopolsky EM, McCann L Bone Turnover Work Group (2004) Diagnosis, assessment, and treatment of bone turnover abnormalities in renal osteodystrophy Am J Kidney Dis. 43:558-565

13. Lefebvre A, de Vernejoul MC, Gueris J, Goldfarb B, Graulet AM, Morieux C (1989) Optimal correction of acidosis changes progression of dialysis osteodystrophy. Kidney Int 36:11121118

14. Carbajo E, Lopez JM, Santos F, Ordonez FA, Nino P, Rodriguez J (2001) Histologic and dynamic change induced by chronic metabolic acidosis in the rat growth plate. J Am Soc Nephrol 12:1228-1234

15. Kalhoff H, Manz F (2001) Nutrition, acid-base status and growth in early childhood. Eur J Nutr 40:221-230

16. Kovacic V, Roguljic L, Kovacic V (2003) Metabolic acidosis of chronically hemodialyzed patients. Am J Nephrol 23:158-164

17. Feriani M, Carobi C, La Greca G, Buoncristiani U, PasslickDeetjen J (1997) Clinical experience with a $39 \mathrm{mmol} / \mathrm{l}$ bicarbonate-buffered peritoneal dialysis solution. Perit Dial Int 17:17-21

18. Coburn JW, Mischel MG, Goodman WG, Salusky IB (1991) Calcium citrate markedly enhances aluminum absorption from aluminum hydroxide. Am J Kidney Dis 17:708-711

19. K/DOQI (2004) Clinical practice guidelines for bone metabolism and disease in chronic kidney disease Epub: www.kidney.org/professionals/kdoqi/guidelines_bone/index.htm

20. Norman LJ, Coleman JE, Macdonald I, Tomsett A, Watson AR (2000) Nutrition and growth in relation to severity of renal disease in children. Pediatr Nephrol 14:833-836

21. Slatopolsky E, Bricker NS (1973) The role of phosphorus restriction in the prevention of secondary hyperparathyroidism in chronic renal disease. Kidney Int 4:141-145

22. Kilav R, Silver J, Naveh-Many T (1995) Parathyroid hormone gene expression in hypophosphatemic rats. J Clin Invest 96:327-333

23. Naveh-Many T, Rahamimov R, Livni N, Silver J (1995) Parathyroid cell proliferation in normal and chronic renal failure rats. The effects of calcium, phosphate, and vitamin D. J Clin Invest 96:1786-1793

24. Almaden Y, Canalejo A, Hernandez A, Ballesteros E, GarciaNavarro S, Torres A, Rodriguez M (1996) Direct effect of 
phosphorus on PTH secretion from whole rat parathyroid glands in vitro. J Bone Miner Res 11:970-976

25. Portale AA, Booth BE, Halloran BP, Morris RC Jr (1984) Effect of dietary phosphorus on circulating concentrations of 1,25-dihydroxyvitamin $\mathrm{D}$ and immunoreactive parathyroid hormone in children with moderate renal insufficiency. J Clin Invest 73:1580-1589

26. Silver J, Yalcindag C, Sela-Brown A, Kilav R, Naveh-Many T (1999) Regulation of the parathyroid hormone gene by vitamin D, calcium and phosphate. Kidney Int [Suppl] 73:S2-7

27. Yi H, Fukagawa M, Yamato H, Kumagai M, Watanabe T, Kurokawa K (1995) Prevention of enhanced parathyroid hormone secretion, synthesis and hyperplasia by mild dietary phosphorus restriction in early chronic renal failure in rats: possible direct role of phosphorus. Nephron 70:242-248

28. Milliner DS, Zinsmeister AR, Lieberman E, Landing B (1990) Soft tissue calcification in pediatric patients with end-stage renal disease. Kidney Int 38:931-936

29. Block GA, Hulbert-Shearon TE, Levin NW, Port FK (1998) Association of serum phosphorus and calcium $\mathrm{x}$ phosphate product with mortality risk in chronic hemodialysis patients: a national study. Am J Kidney Dis 31:607-617

30. Huting J (1994) Mitral valve calcification as an index of left ventricular dysfunction in patients with end-stage renal disease on peritoneal dialysis. Chest 105:383-388

31. Ribeiro S, Ramos A, Brandao A, Rebelo JR, Guerra A, Resina C, Vila-Lobos A, Carvalho F, Remedio F, Ribeiro F (1998) Cardiac valve calcification in haemodialysis patients: role of calcium-phosphate metabolism. Nephrol Dial Transplant 13:2037-2040

32. Moe SM, O'Neill KD, Duan D, Ahmed S, Chen NX, Leapman SB, Fineberg N, Kopecky K (2002) Medial artery calcification in ESRD patients is associated with deposition of bone matrix proteins. Kidney Int 61:638-647

33. Shioi A, Taniwaki H, Jono S, Okuno Y, Koyama H, Mori K, Nishizawa Y (2001) Monckeberg's medial sclerosis and inorganic phosphate in uremia. Am J Kidney Dis 38 [Suppl 1]:S4749

34. Amann K, Tornig J, Kugel B, Gross ML, Tyralla K, El-Shakmak A, Szabo A, Ritz E (2003) Hyperphosphatemia aggravates cardiac fibrosis and microvascular disease in experimental uremia. Kidney Int 63:1296-1301

35. Coleman JE, Edefonti A, Watson AR on behalf of the European Pediatric Peritoneal Working Group (2001) Guidelines by an ad hoc European committee on the assessment of growth and nutritional status in children on chronic peritoneal dialysis. Perit Dial Int 21:323 (www.ispd.org.guidelines)

36. Schaefer F, Langenbeck D, Heckert KH, Scharer K, Mehls O (1992) Evaluation of peritoneal solute transfer by the peritoneal equilibration test in children. Adv Perit Dial 8:410-415

37. Fischbach M, Boudailliez B, Foulard M (1997) Phosphate end dialysis value: a misleading parameter of hemodialysis efficiency. Pediatr Nephrol 11:193-195

38. Maasrani M, Jaffrin MY, Fischbach M, Boudailliez B (1995) Urea creatinine and phosphate kinetic modelling during dialysis: application to pediatric hemodialysis. Int J Artif Organs 18:122-129

39. Bell L, Espinosa P (2003) Intensive in center hemodialysis for children: a case for longer dialysis duration. Hemodial Int 7:290-295

40. Maduell F, Navarro V, Torregrosa E, Rius A, Dicenta F, Cruz MC, Ferrero JA (2003) Change from three times a week on line hemodiafiltration to short daily on line hemodiafiltration. Kidney Int 64:305-313

41. Traeger S, Galland R, Arkouche W, Delawari E, Fouque D (2001) Short daily hemodialysis: a 4-year experience. Dialysis Transplant 30:76-86

42. Fischbach M, Hamel G, Simeoni U, Geisert J (1992) Phosphate dialytic removal: enhancement of phosphate cellular clearance by biofiltration (with acetate free buffer dialysate). Nephron 62:155-160
43. Fischbach M, Terzic J, Cousandier E, Hamel G, Geisert J (1998) Glucose charged dialysate for children on hemodialysis: acute dialytic changes. Pediatr Nephrol 12:60-62

44. Fischbach M, Terzic J, Laugel V, Dheu C, Menouer S, Helms P, Livolsi A (2004) Daily on line hemodiafiltration: a pilot experience in children. Nephrol Dial Transpl (submitted)

45. Schiller LR, Santa Ana CA, Sheikh MS, Emmett M, Fordtran JS (1989) Effect of the time of administration of calcium acetate on phosphorus binding. New Engl J Med 27:1110-1113

46. Wallot M, Bonzel KE, Winter A, Georger B, Lettgen B, Bald M (1996) Calcium acetate versus calcium carbonate as oral phosphate binder in pediatric and adolescent hemodialysis patients. Pediatr Nephrol 10:625-630

47. Pflanz S, Henderson IS, McElduff N, Jones MC (1994) Calcium acetate versus calcium carbonate as phosphate-binding agents in chronic haemodialysis. Nephrol Dial Transplant 9:1121-1124

48. Lowrie EG, Lew NL (1990) Death risk in hemodialysis patients: the predictive value of commonly measured variables and an evaluation of death rate differences between facilities. Am J Kidney Dis 15:458-482

49. D'Haese PC, Spasovski GB, Sikole A, Hutchison A, Freemont TJ, Sulkova S, Swanepoel C, Pejanovic S, Djukanovic L, Balducci A, Coen G, Sulowicz W, Ferreira A, Torres A, Curic S, Popovic M, Dimkovic N, De Broe ME (2003) A multicenter study on the effects of lanthanum carbonate (Fosrenol) and calcium carbonate on renal bone disease in dialysis patients. Kidney Int [Suppl] 85:S73-78

50. Fernandez-Gavarron F, Huque T, Rabinowitz JL, Brand JG (1988) Incorporation of 140-lanthanum into bones, teeth and hydroxyapatite. Bone Miner 3:283-291

51. Reichel H, Deibert B, Schmidt-Gayk H, Ritz E (1991) Calcium metabolism in early chronic renal failure: implications for the pathogenesis of hyperparathyroidism. Nephrol Dial Transplant 6:162-169

52. Dusso A, Lopez-Hilker S, Rapp N, Slatopolsky E (1988) Extrarenal production of calcitriol in chronic renal failure. Kidney Int 34:368-375

53. Van der Wielen RP, Lowik MR, van den Berg H, de Groot LC, Haller J, Moreiras O, van Staveren WA (1995) Serum vitamin D concentrations among elderly people in Europe. Lancet 346:207-210

54. Birge SJ, Haddad JG (1975) 25-hydroxycholecalciferol stimulation of muscle metabolism. J Clin Invest 56:1100-1107

55. Ritz E, Küster S, Schmidt-Gayk H, Stein G, Scholz C, Kraatz G, Heidland A (1995) Low-dose calcitriol prevents the rise in 1,84-iPTH without affecting serum calcium and phosphate in patients with moderate renal failure (prospective placebo-controlled multicentre trial). Nephrol Dial Transplant 10:22282234

56. Waller S, Ledermann S, Trompeter R, van't Hoff W, Ridout D, Rees L (2003) Catch-up growth with normal parathyroid hormone levels in chronic renal failure. Pediatr Nephrol 18:12361241

57. Salusky IB, Ramirez JA, Oppenheim W, Gales B, Segre GV, Goodman WG (1994) Biochemical markers of renal osteodystrophy in pediatric patients undergoing CAPD/CCPD. Kidney Int 45:253-258

58. Piscitelli J, Cabansag MR, Silverstein DM (1999) Correlation among markers of renal osteodystrophy in pediatric hemodialysis patients. J Pediatr Endocrinol Metab 12:879-886

59. Klaus G, Mehls O, Hinderer J, Ritz E (1991) Is intermittent oral calcitriol safe and effective in renal secondary hyperparathyroidism? Lancet 337:800-801

60. Ballanti P, Wedard BM, Bonucci E (1996) Frequency of adynamic bone disease and aluminum storage in Italian uraemic patients-retrospective analysis of 1,429 iliac crest biopsies. Nephrol Dial Transplant 11:663-667

61. Kuizon BD, Goodman WG, Juppner H, Boechat I, Nelson P, Gales B, Salusky IB (1998) Diminished linear growth during intermittent calcitriol therapy in children undergoing CCPD. Kidney Int 53:205-211 
62. Shigematsu T, Kawaguchi Y, Kubo H, Nakayama M, Kato N, Yamamoto H, Osaka N, Hayakawa H, Ogawa A, Sakai O (1996) Low calcium (1.25 mmol/l) dialysate can normalize relative hypoparathyroidism in CAPD patients with low bone turnover. Adv Perit Dial 12:250-256

63. Ardissino G, Schmitt CP, Testa S, Claris-Appiani A, Mehls O (2000) Calcitriol pulse therapy is not more effective than daily calcitriol therapy in controlling secondary hyperparathyroidism in children with chronic renal failure. European Study Group on Vitamin D in Children with Renal Failure. Pediatr Nephrol $14: 664-668$

64. Tsuruoka S, Wakaumi M, Sugimoto K, Saito T, Fujimura A (2003) Chronotherapy of high-dose active vitamin D3 in haemodialysis patients with secondary hyperparathyroidsm: a repeated dosing study.Br J Clin Pharmacol 55:531-537

65. Goodman WG, Ramirez JA, Belin TR, Chon Y, Gales B, Segre GV, Salusky IB (1994) Development of adynamic bone in patients with secondary hyperparathyroidism after intermittent calcitriol therapy. Kidney Int 46:1160-1166

66. Klaus G, König B, Hügel U, Ritz E, Mehls O (1993) Intermittent and continuous exposure to $1,25(\mathrm{OH}) 2 \mathrm{D} 3$ have different effects on growth plate chondrocytes in vitro. Kidney Int 44:708-715

67. Mehls O, Knoller N, Oh J, Wesch H, Wunsche B, Schmitt CP (2000) Daily but not pulse calcitriol therapy improves growth in experimental uremia. Pediatr Nephrol 14:658-663

68. Schmitt CP, Ardissino G, Testa S, Claris-Appiani A, Mehls O (2003) Growth in children with chronic renal failure on intermittent versus daily calcitriol. Pediatr Nephrol 18:440-444

69. Ardissino G, Schmitt CP, Bianchi ML, Dacco V, Claris-Appiani A, Mehls O (2000) No difference in intestinal strontium absorption after oral or IV calcitriol in children with secondary hyperparathyroidism. The European Study Group on Vitamin D in Children with Renal Failure. Kidney Int 58:981-988

70. Herrmann P, Ritz E, Schmidt-Gayk H, Schafer I, Geyer J, Nonnast-Daniel B, Koch KM, Weber U, Horl W, Haas-Worle A (1994) Comparison of intermittent and continuous oral administration of calcitriol in dialysis patients: a randomized prospective trial. Nephron 67:48-53

71. Sprague SM, Llach F, Amdahl M, Taccetta C, Batlle D (2003) Paricalcitol versus calcitriol in the treatment of secondary hyperparathyroidism. Kidney Int 63:1483-1490

72. Block GA, Martin KJ, de Francisco AL, Turner SA, Avram MM, Suranyi MG, Hercz G, Cunningham J, Abu-Alfa AK, Messa P, Coyne DW, Locatelli F, Cohen RM, Evenepoel P, Moe SM, Fournier A, Braun J, McCary LC, Zani VJ, Olson KA, Drueke TB, Goodman WG (2004) Cinacalcet for secondary hyperparathyroidism in patients receiving hemodialysis. N Engl J Med 350:1516-1525

73. Tönshoff B, Blum WF, Mehls O (1997) Derangements of the somatotropic hormone axis in chronic renal failure. Kidney Int [Suppl] 58:S106-113
74. Haffner D, Schaefer F, Nissel R, Wuhl E, Tonshoff B, Mehls O (2000) Effect of growth hormone treatment on the adult height of children with chronic renal failure. German Study Group for Growth Hormone Treatment in Chronic Renal Failure. N Engl J Med 343:923-930

75. Wang J, Zhou J, Cheng CM, Kopchick JJ, Bondy CA (2004) Evidence supporting dual, IGF-I-independent and IGF-I-dependent, roles for $\mathrm{GH}$ in promoting longitudinal bone growth. J Endocrinol 180:247-255

76. Olney RC (2003) Regulation of bone mass by growth hormone. Med Pediatr Oncol 41:228-234

77. Loder RT, Hensinger RN (1997) Slipped capital femoral epiphysis associated with renal failure osteodystrophy. J Pediatr Orthop 17:205-211

78. Fine RN, Ho M, Tejani A, Blethen S (2003) Adverse events with rhGH treatment of patients with chronic renal insufficiency and end-stage renal disease. J Pediatr 142:539-545

79. Berard E, Crosnier H, Six-Beneton A, Chevallier T, Cochat P, Broyer M (1998) Recombinant human growth hormone treatment of children on hemodialysis. French Society of Pediatric Nephrology. Pediatr Nephrol 12:304-310

80. Picca S, Cappa M, Martinez C, Moges SI, Osborn J, Perfumo F, Ardissino G, Bonaudo R, Montini G, Rizzoni G (2004) Parathyroid hormone levels in pubertal uremic adolescents treated with growth hormone. Pediatr Nephrol 19:71-76

81. Fukagawa M, Kitaoka M, Yi H, Fukuda N, Matsumoto T, Ogata E, Kurokawa K (1994) Serial evaluation of parathyroid size by ultrasonography is another useful marker for the longterm prognosis of calcitriol pulse therapy in chronic dialysis patients. Nephron 68:221-228

82. Okuno S, Ishimura E, Kitatani K, Chou H, Nagasue K, Maekawa K, Izumotani T, Yamakawa T, Imanishi Y, Shoji T, Inaba M, Nishizawa Y (2003) Relationship between parathyroid gland size and responsiveness to maxacalcitol therapy in patients with secondary hyperparathyroidism. Nephrol Dial Transplant 18:2613-2621

83. Kakuta T, Fukagawa M, Fujisaki T, Hida M, Suzuki H, Sakai H, Kurokawa K, Saito A (1999) Prognosis of parathyroid function after successful percutaneous ethanol injection therapy guided by color Doppler flow mapping in chronic dialysis patients. Am J Kidney Dis 33:1091-1099

84. Schömig M, Ritz E (2000) Management of disturbed calcium metabolism in uraemic patients: 2 . Indications for parathyroidectomy. Nephrol Dial Transplant 15 [Suppl 5]:25-29

85. Quarles LD, Sherrard DJ, Adler S, Rosansky SJ, McCary LC, Liu W, Turner SA, Bushinsky DA (2003) The calcimimetic AMG 073 as a potential treatment for secondary hyperparathyroidism of end-stage renal disease. J Am Soc Nephrol $14: 575-583$ 